\title{
Research on the case teaching model of business administration specialty in undergraduate course
}

\author{
Yan Xiong \\ Nanchang Institute of Technology \\ Nanchang city, Jiangxi province \\ 330108
}

Keywords: case teaching, business administration, undergraduate course

\begin{abstract}
The case teaching model first originated in the United States at Harvard University, because of its incomparable superiority, it has been valued and applied in more and more business colleges, also has become the important reform direction of teaching mode for business administration in China. This article mainly discusses the application and problems have been encountered of case teaching mode in the class of Business Administration Specialty in undergraduate course at present .

According to the development of the present era, social demand for talents more and more high quality, and according to the training objective of business administration specialty, this specialty mainly has a strict requirement for students' team spirit and innovation ability, etc, the training goal is to improve the student's own management and the ability of autonomous learning. According to the current traditional teaching model in promoting the students' comprehensive quality has no significant effect, or the talents trained have been unable to keep up with the changes of social demand, so we need to change this kind of teaching model, to discover new teaching model and can improve students' comprehensive quality.
\end{abstract}

\section{Present situation of case teaching in business administration specialty}

In the past teaching model, usually use cramming teaching, this model mainly emphasizes theoretical knowledge system in the textbook. Teacher is the main body of the classroom who has absolute certainty for progress and content of teaching, has very important authority, the teaching model is to transfer the knowledge, transfer conclusive things from teachers to students, so the result for this kind of teaching model is that students finally formed a complete knowledge system, have complete knowledge reserve, but have no thinking, thinking and judging ability has been weakened, lack of necessary independence and thinking autonomy, and the mechanical learning can't stimulate students' learning enthusiasm and seeking knowledge desire, at the same time, in the specific application process, lack of the transition of theory applied to the practice.

Business administration as a specialty that theory and practice are all very important, should abandon the traditional teaching model, use typical case teaching, use enterprise's real materials and practical experience as a guide for teaching, let students excavate knowledge by themselves, use the learned knowledge to solve the problems, and this kind of case teaching model is conductive to cultivate students' autonomous decision-making ability and team cooperation ability. Case teaching model is consistent with students' cognitive process, summarize and grasp knowledge from practice to strengthen students' study effect has a very significant role. The process of case teaching carried out in the business administration specialty is: the teacher will provide related theoretical concepts for the students, and then utilize corresponding cases which from books or found by himself to help students understand and remember learned knowledge, or let students analyze by themselves, but this kind of analysis is also under the teacher's constant reminding, then the teacher will explain and analyze the thinking of this kind of case, to make the students understand the thinking direction and learning goals. Although compared with the traditional teaching model has a big improvement, but this kind of case teaching is also mastered by the teachers, teachers are still the main body of the classroom. Another is that the case is usually selected by teachers' experience. In this case, for the analysis of the case, the students will tend to focus on to guess the answers, rather than to use their 
own knowledge system or their own independent thinking way to analyze the problem. So for the result of this kind of circumstance is that the students don't find his body position, have no way to put forward the critical point of all kinds of ideas and technology. For many cases, there is no standard answer, from a different angle to analyze will get different conclusions and views, so in order to give full play to the effectiveness of case teaching, also need to carry out the corresponding reform and innovation for current model.

\section{The application of case teaching in undergraduate teaching}

(1) Clear the particularity of undergraduates

Although the case analysis method in the teaching of undergraduate and graduate students are equally important, but they have a very big difference in breadth and depth of knowledge, the thinking mode and thinking ability. Therefore, learning the theoretical knowledge well is the foundation, it is important that advocating the case teaching model is not to negate the traditional teaching model, the two are inseparable dialectical relationship. If students have a little knowledge of marketing, strategy and human resource management, blindly teach cases can only be swallowed. So the case teaching model does not have to take the whole case from abroad, and should be made to match the theoretical study. On the case preparation and classroom teaching, all must consider the particularity of undergraduates.

A. On the aspect of the case preparation, should fully consider the knowledge reserve status of undergraduates. (1) Theoretical knowledge of undergraduate is not stronger than graduate, so providing case should not be as long as foreign, and have high requirement on aspects of analyzing the details,etc, but should take some cases with short refining and closer from the student life. In this way, can stimulate students' interest in learning, but also can fully consider the limits of knowledge. (2) On the aspect of case subject, we should give priority to with domestic famous enterprises subject, that is localization principle. If provide the cases of foreign for students to study, not only make students produce strangeness, at the same time, it is not suitable for them to understand the special national conditions of enterprise development in our country. (3) Keep the truth of case, case credibility from the neutral attitude of the authors, when discuss a variety of views using raw materials of interview, avoid by all means to join the teachers' own tendency .

B. In classroom teaching, teachers should fully pay attention to the problem of role definition, mainly reflects in: (1)Master of classroom rhythm, namely in the limited time, how can let more students to put forward his own point of view, how can try hard to control the situation in the case of students debate over and so on. The classroom task whether can be completed on time, to a large extent depends on the teachers mastering the classroom rhythm. (2)Excited people of thinking, it is easy to fall into acrimony of individual students in the classroom, while other students is in a state of bystanders. Therefore, the teacher must be sought to make every student's thinking in a workout, not only focus on few students. (3)Conclusion, students often speak in disorder. Therefore, when students speak, the teacher must quickly write down and organize the speech thinking of students, and summarize different points of view.

(2) Carry out case teaching model of undergraduate course can be divided into three stages

A. Students' case preparation stage. Teachers can decorate the case which next class will be taught to students a few days in advance. Both the students can be grouped by teacher, also free to group by themselves, each group of four to five people. At the same time, considering the non-adaptability of undergraduates for case analysis, the teacher should explain that the requirements of the case analysis and the purpose need to achieve. Carrying out case analysis model first, the teacher can provide direction, thinking and main points of case analysis for students, and recommend the relevant books. Team members should have a clear division of labor, are responsible for looking for their respective areas of related information, and do a good job of integration. In the group discussion, everyone should be record the collection integrating results of other team members, achieve resource integration and sharing.

B. Classroom teaching stage. (1)Speaking stage. Teachers should look for a student, the first to 
speak out his (her) research, speaking time should be controlled between 10 to 20 minutes. (2) Free discussion stage. After this student completed to speak, other students can put forward their own ideas for this student's speaking, can refute, also can put forward the better constructive suggestions, and so on. (3) Conclusion stage. After the students free discussion, the teacher should summarize various views of students, and express his own opinions, comment on students' speaking. In these three stages, the teacher first should pay attention to actively mobilize the students' participation, avoid by all means to appear the situation of "stage wait". At the same time, the teacher should hold presentation time well, let more students to participate in the speech. Second is to pay attention to excavate students' thought. When student speaking finished, teacher can put forward more questions in view of student's speaking, guide the student to go to a deeper level thinking, broaden the thinking ways of student. Third is to do the record and integrating work earnestly. In the process of student speaking, teacher should record the thinking of student speaking quickly on the blackboard, concentrate on the main points, easy to let other students understand his speech. Fourth, the students speaking should be free speaking, don't have to assign each team representatives to speak according to the groups. On the existing teaching model, is generally discuss in groups, designate representatives of groups while speaking. This model looks to mobilize the students' participation, but actually has a lot of disadvantages. The eloquence of speaking students often is relative good, therefore, not only students who eloquence is week and shy can't get a chance to speak in class, also can let them to produce a kind of dependence, namely no tension feel, because speaking work never to do by themselves. Therefore, the teacher not only should encourage students to actively raise their hands to speak, speak the research results that his team readied, teachers should also consciously pay attention to the students who do not love to speak, exercise their courage and confidence, and make everyone feel stressed, make them feel that the next person to speak are likely to be themselves, then can effectively focus the students attention, improve the classroom efficiency.

C. Case teaching evaluation phase. Case teaching evaluation is an important part of the comprehensive evaluation as the teaching organization. Evaluation can be divided into three aspects: (1) For the evaluation of case content. Such as consider the undergraduate level, whether the students are too complex to understand the case content, how much theory knowledge can be applied. (2) The length of time in class discussion. Such as whether discuss, discuss whether into a "dead end", whether dig out more valuable opinions in the limited time. (3) Whether case preparation takes too much of your time, whether case selection is appropriate. (4) The proportion of cases and theory. Whether case teaching takes too much time in theory teaching, evaluation can once a month. The teachers can according to the reflection of students, adjust the teaching plan appropriately.

\section{The advantage of case teaching model}

Case teaching model is conductive to cultivate the students' leading consciousness. Case teaching model is to show the living examples in the classroom which happened in the enterprise, through the analysis and discussion of the students, let students play various roles and make the decisions, is very important to cultivate the students' analysis ability, innovation ability and the ability to deal with the problem flexibly when unforeseen situation happened. Therefore, make the student have such quality, it is not possible by force-feeding teaching methods. Case teaching is the best way to cultivate students' innovation ability and hone their will.

\section{References}

[1]Shenggang Ren. The particularity and thinking of case teaching model in business administration specialty in undergraduate course f J1. Economist, 2005, (03).

[2]Rui Long. The MBA case encyclopedia in Harvard Business School[M]. Beijing: Economic daily press. 1998. 
[3]Wei Sun, etc. The practice and its enlightenment of America's top business administration specialty for undergraduate IEB/OL]. ht t p: / / www. 1 wl m. com/gaodengji aoyu. 2008-10-15.

[4]Dexin zou, etc. Case study and its application in the teaching of western economics [J]. Journal of Liaoning Economic Vocational and Technical College, 2009, (03).

[5]Jianxin Ma, Qinghua Li. Business administration case teaching and learning methods [M]. Beijing: Beijing Normal University press, 2008. 